\title{
Topical Lidocaine for Chronic Pain Treatment
}

\author{
Marion Voute' \\ Véronique Morel ${ }^{1}$ \\ Gisèle Pickering ${ }^{1,2}$ \\ 'CHU Clermont-Ferrand, Plateforme \\ d'Investigation Clinique - Centre \\ d'Investigation Clinique, CIC Inserm \\ 1405, Clermont-Ferrand, F-63000, \\ France; ${ }^{2}$ Université Clermont Auvergne, \\ Inserm I 107, Clermont-Ferrand, \\ F-63000, France
}

\begin{abstract}
Topical lidocaine is widely used in current practice for a variety of pain conditions. This literature review shows that its limited absorption and relative lack of systemic adverse events are an attractive analgesic option for a number of vulnerable patients. Topical lidocaine has been approved by health authorities for the treatment of post-herpetic neuralgia in a number of countries, and studies present some degree of evidence of its efficacy and safety in postsurgical pain, diabetic peripheral neuropathy, carpal tunnel syndrome, chronic lower back pain and osteoarthritis. Topical lidocaine may be a great alternative alone or in addition to systemic drugs and non-pharmacological approaches for an optimized pain management and in multimodal analgesia.
\end{abstract}

Keywords: lidocaine plaster, topical, local, neuropathic pain, musculoskeletal pain

\section{Introduction}

Pain treatment is a major health concern and often limited by safety hazards of systemic drugs. ${ }^{1}$ In Europe, the prevalence of chronic pain is estimated to affect $25-30 \%$ of the population. ${ }^{2}$ Despite recommended treatments, more than $60 \%$ of patients suffering from chronic pain show no improvement or a poor response and often experience adverse effects (AE). ${ }^{3}$ Recommendations for chronic pain treatment underline that topical agents could be used as first- or second-line treatment by International Pain Guidelines. ${ }^{4-9}$ Interest in and use of topical analgesics have been increasing because of their potential efficacy in acute and chronic pain and relative lack of systemic AEs.

Lidocaine, an amino amide anesthetic. has been approved in the United States in the $1940 \mathrm{~s}^{10}$ and is largely used in clinical practice. In the $1990 \mathrm{~s}$, a patch formulation of lidocaine 5\% was developed and approved by the Food and Drug Administration (FDA) for the treatment of postherpetic neuralgia (PHN). ${ }^{3,11}$

Considering the pharmacokinetics of $5 \%$ lidocaine plaster (5LP), each plaster contains $700 \mathrm{mg}$ of lidocaine for which a maximum of three plasters applied simultaneously for 12 hours is allowed. ${ }^{12}$ Only $3 \% \pm 2 \%$ of this maximum recommended dose is systemically absorbed and more than 95\% (665mg) remain in the applied medicated plaster. Once absorbed, lidocaine binds predominantly to alpha-1- acid glycoprotein and presumably diffuses passively across the placental and blood-brain barriers. Lidocaine is metabolized in the liver to non-active metabolites that are excreted by the kidneys with an elimination half-life of 7.6 hours. A dosage adjustment is however not required. ${ }^{12}$

Concerning its pharmacodynamics, lidocaine is a non-selective, voltage-gated sodium channel blocker (especially Nav 1.7 and 1.8) on sensory afferents of small damaged or dysfunctional pain fibers at the site of application. ${ }^{13}$ It acts by
Correspondence: Gisèle Pickering $\mathrm{CHU}$ Clermont-Ferrand, Plateforme d'Investigation Clinique - Centre d'Investigation Clinique, $\mathrm{CIC}$ Inserm 1405, Clermont-Ferrand, F-63000, France

Tel +33473 I784 16

Fax $+33473 \quad 1784 \quad 12$

Email gisele.pickering@uca.fr 
stabilizing neuronal membranes and affects both the generation and conduction of nerve impulses (reduction of ectopic discharge and signal propagation in A delta and C fibers). Lidocaine may also activate some irritant receptors (TRPV1, TRPA1) on keratinocytes and immune cells contributing to its analgesic effect. ${ }^{14}$

Considering the large use of topical lidocaine worldwide, this review focuses on the literature, reviews and randomised clinical trials (RCTs) to evaluate how topical lidocaine may be a valuable alternative for an optimized pain management and in multimodal analgesia.

\section{Methods}

\section{Search Strategy}

A literature review was conducted through an exhaustive electronic search of Medline, PubMed, Google Scholar, and Cochrane databases. Key words such as "topical lidocaine", "lidocaine patch", "lidocaine plaster", "chronic pain", "postsurgical persistent pain", "postherpetic neuralgia", "diabetic peripheral neuropathy", "carpal tunnel syndrome", "chronic lower back pain" and "osteoarthritis pain" were used without limitation in language or date of publication. The last search was conducted in May 2021. This manuscript adheres to the applicable PRISMA guidelines.

\section{Study Selection}

Our search was restricted to meta-analyses, parallel and cross-over randomized controlled trials (RCTs) and prospective studies, comparing topical lidocaine to controls. This search included studies concerning lidocaine as a pharmacological drug to treat pain. Inclusion criteria were established prior to article review:

- Design: meta-analyses, double- or single-blind, cross-over or parallel, versus placebo or active control RCTs; prospective studies.

- Etiology: Neuropathic pain (postsurgical persistent pain (PSPP); PHN; diabetic peripheral neuropathy (DPN); carpal tunnel syndrome), musculoskeletal pain (chronic lower back pain (CLBP); osteoarthritis pain (OA)).

- Outcomes (primary or secondary): topical lidocaine efficacy defined by a significant change in pain using diverse measures (Numerical rating scale score (NRS), Dynamic mechanical allodynia (DMA), Visual Analog Scale score (VAS), median-to-exit, response rate, Neuropathic Pain Scale (NPS), Average Pain Intensity (API), Western Ontario and McMaster Universities Arthritis Index (WOMAC)).

During the selection process, all studies not related to lidocaine (animal studies, protocols, letters to editors, expert opinions, or comments) have been excluded after selection based on the title, abstract, and full text, if necessary. Due to language limitations, this review only included articles in English with no limitation on study year or country. Two researchers independently reviewed the papers, and discrepancies were resolved through discussion and consensus.

\section{Data Extraction and Analysis}

Data for the selected studies were extracted as follows: study design, characteristics of subjects, pain types and control groups, outcome measurements and effectiveness. Pain types were classified as NP and musculoskeletal pain. NP was divided in PSPP, PHN, DPN and carpal tunnel syndrome and musculoskeletal pain was divided in CLBP and OA.

\section{Risk of Bias Assessment}

This review is a scoping review, and risk assessment was focused on blinding and randomization, but did not evaluate selection attrition or other biases.

\section{Results}

A total of 3366 articles were identified after database research and 112 were eligible for this review. After having discarded duplicates, screened abstracts, and removed excluded publications (Figure 1), 43 articles were included in this review: 5 meta-analyses/systematic reviews, 3 Cochrane reviews and 23 RCTs. Furthermore, 12 prospective studies have been identified.

\section{Non-Specific Chronic Pain}

A number of publications included studies with several chronic pain etiologies, PSPP, PHN, DPN or CLBP and did not analyse their population according to each etiology. According to studies, lidocaine plaster reduces neuropathic symptoms and allodynia in patients with peripheral painful neuropathy, compared to placebo. ${ }^{15,16}$ Furthermore, in healthy volunteers and patients, the lidocaine-medicated plaster causes variable effects on different sensory thresholds (cold, warmth, touch, hot pain and mechanical pain). ${ }^{17}$ Reduction of the allodynia area is an important factor in the 


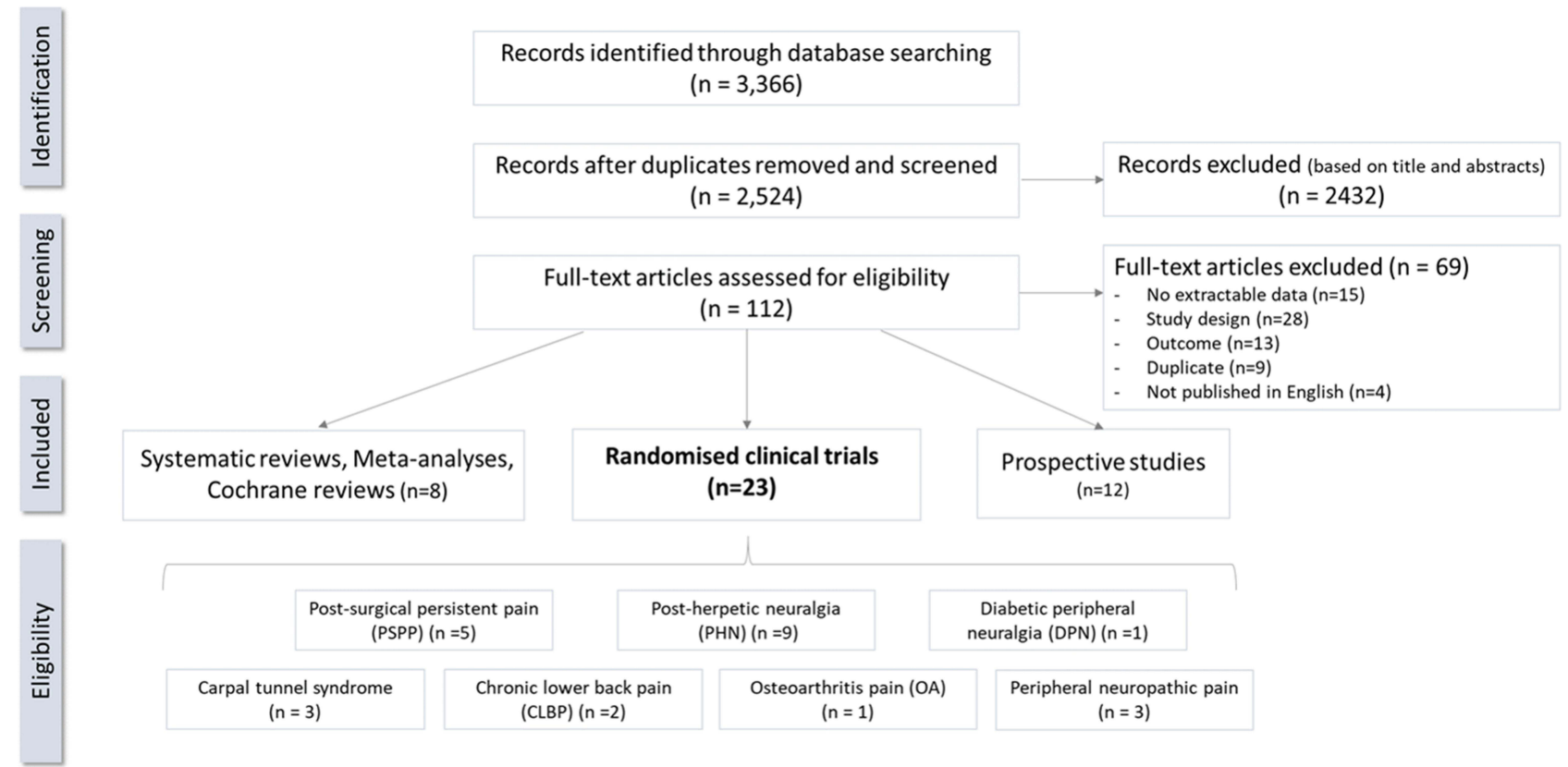

Figure I Flowchart of the literature on topical lidocaine.

improvement of quality of life. ${ }^{17,18}$ Thus, a systematic review and meta-analysis realized on 229 articles showed weak GRADE recommendations but proposed 5LP in second line. It has been recommended for PNP and especially in elderly patients where 5LP becomes first-line option. ${ }^{4}$ Another systematic review and network meta-analysis including 43 RTCs evaluated efficacy and safety of lidocaine $700 \mathrm{mg}$ medicated plaster versus (vs) pregabalin. This review describes no clear difference in efficacy between treatments but 5LP shows better AE profile. ${ }^{19}$ Regarding Cochrane reviews, Derry et al found no evidence from good-quality RCTs to recommend use of lidocaine in NP although clinical experience and individuals' studies present improvement in pain relief. $^{20,21}$ However, a randomized controlled study realized in 46 patients with PNP with 4-week treatment shows a reduction in pain of $0.3 \mathrm{NRS}$ points $(95 \%$ confidence interval [CI]: $0.1-0.5)$ and pain-related sleep disturbance of 0.6 points $(95 \% \mathrm{CI}: 0.4-0.8)$ over placebo $(\mathrm{p}=0.007$ and $\mathrm{p}<$ $0.001)$ and significant pain relief $(\mathrm{p}=0.036)$ (Table 1$)^{22}$ Another study with 5\% lidocaine cream realized on 35 patients with PSPP, PHN or DPN demonstrates a significant reduction in pain intensity with topical lidocaine. ${ }^{23}$ Meier et al, 2003 describes that, as an add-on therapy, 5LP was effective in reducing ongoing pain $(\mathrm{p}=0.017)$ and allodynia $(p=0.023)$ during the first hours after application and over a period of 7 days $(p=0.018)$ in diverse PNP. ${ }^{15}$ Finally, a prospective study with patients suffering from PHN, DPN or CLBP shows a significant effectiveness (using the Brief Pain Inventory measures) in all groups with a good tolerability (Table 1$).^{24}$

\section{Neuropathic Pain}

Neuropathic pain, a type of chronic pain, is a pathological process in the peripheral or central nervous system (CNS) and presents as one of the most challenging pain syndromes to identify and treat. Its worldwide prevalence is estimated to be $6.9-10 \%$ in the global population. ${ }^{25}$ It is defined as "pain that arises as a direct consequence of lesion or disease affecting the somatosensory system". 26 Examples of NP include PHN, ${ }^{17,27}$ DPN $^{28}$ carpal tunnel syndrome ${ }^{29}$ and PSPP. ${ }^{17,30,31}$ PSPP is frequently reported in the literature as a disabling complication of many surgical procedures. Nerve injuryinduced NP has repeatedly been proposed as a major cause of PSPP. ${ }^{32}$ Studies on neuropathic characteristics of PSPP have been carried out mostly on patients undergoing procedures associated with a high incidence of nerve injury, including breast cancer surgery, ${ }^{30,33}$ thoracotomy, ${ }^{34}$ inguinal hernia repair ${ }^{35}$ and limb amputation. ${ }^{36}$

Concerning PSPP, a total of five RCTs and one prospective study focused on PSPP have been retrieved: four studies did show a positive result and two studies did not show reduction of pain with 5 LP. ${ }^{17,30,37-39} \mathrm{~A}$ randomized controlled trial demonstrates the effectiveness of 5LP on several neuropathic characteristics, in psychophysical responses and 
Table I Randomized Clinical Trials with Topical Lidocaine in Non-Specific Chronic Pain

\begin{tabular}{|c|c|c|c|c|c|c|c|c|}
\hline Authors & Population & Design* & Treatment & $\begin{array}{c}\text { Sample } \\
\text { Size }\end{array}$ & $\begin{array}{c}\text { Maximum } \\
\text { Dose/Nb } \\
\text { of Plasters }\end{array}$ & $\begin{array}{c}\text { Follow- } \\
\text { Up } \\
\text { Weeks }\end{array}$ & $\begin{array}{c}\text { Concomitant } \\
\text { Medication }\end{array}$ & Primary Outcome \\
\hline $\begin{array}{l}\text { Demant } \\
\text { et al, } \\
2015^{22}\end{array}$ & $\begin{array}{l}\text { Peripheral } \\
\text { neuropathic } \\
\text { pain (NP, } \\
\text { PSPP, PHN) }\end{array}$ & & $\begin{array}{l}5 \% \text { Lidocaine } \\
\text { plaster } \\
\text { ( } n=N R \text { ) vs } \\
\text { Placebo } \\
\text { ( } n=N R \text { ) } \\
\text { Irritable } \\
\text { nociceptor } \\
\text { vs non } \\
\text { irritable } \\
\text { nociceptor }\end{array}$ & $\begin{array}{c}\text { NR } \\
15 \\
25\end{array}$ & 3 & 4 & No & $\begin{array}{l}\text { NRS and pain-related sleep } \\
\text { disturbance reduced }(p= \\
0.007 \text { and } p<0.001)\end{array}$ \\
\hline $\begin{array}{l}\text { Ho et al, } \\
2008^{23}\end{array}$ & $\begin{array}{l}\text { PSPP, PHN, } \\
\text { DPN }\end{array}$ & & $\begin{array}{l}5 \% \text { Lidocaine } \\
\text { cream vs } 5 \% \\
\text { amitriptyline } \\
\text { cream vs } \\
\text { Placebo }\end{array}$ & $\begin{array}{l}35 \\
35 \\
35\end{array}$ & $6-10 \mathrm{~mL}$ & 6 & Yes & VAS score reduction $(p<0.05)$ \\
\hline $\begin{array}{l}\text { Meier } \\
\text { et al, } \\
2003^{15}\end{array}$ & $\begin{array}{l}\text { Peripheral } \\
\text { neuropathic } \\
\text { pain }\end{array}$ & & $\begin{array}{l}\text { Group I: } 5 \% \\
\text { Lidocaine } \\
\text { plaster- } \\
\text { placebo } \\
\text { Group 2: } \\
\text { Placebo - 5\% } \\
\text { lidocaine } \\
\text { paster } \\
(n=20)\end{array}$ & $\begin{array}{l}20 \\
20\end{array}$ & 4 & 3 & Yes & $\begin{array}{l}\text { Ongoing pain }(p=0.017) \text { and } \\
\text { allodynia }(p=0.023) \text { reduction } \\
\text { during the first } 8 \mathrm{~h} \text { after } \\
\text { application and over a period } \\
\text { of } 7 \text { days }(p=0.018)\end{array}$ \\
\hline
\end{tabular}

Note: *All studies are randomized, double blind, crossover and versus (vs) placebo, unless specified.

Abbreviations: PSPP, posttraumatic/post-surgical persistent pain; PHN, postherpetic neuralgia; DPN, diabetic peripheral neuropathy; NR, not reported; No, no concomitant medication.

clinical allodynic symptoms (Table 2). ${ }^{17}$ Another study describes a clinically relevant reduction of pain in the $5 \mathrm{LP}$ arm where the pain reduction was numerically higher than in the placebo but without effect statistically significant (least squares mean [LS mean] [standard error] for placebo plaster -1.47 [0.16] versus -1.70 [0.16] for lidocaine; [LS] difference [SE] between treatments -0.23 [0.23], one-sided $\mathrm{p}=0$ 0.1533). ${ }^{37}$ Furthermore, Sansone et al show a significant greater reduction in pain score in the 5LP group compared with the placebo group (baseline to week $4,-2.9$ vs -0.7 , $\mathrm{p}<0.01 ;$ baseline to week $8,-4.3$ vs $0.0, \mathrm{p}<0.01) .{ }^{38}$ A prospective observational study describes that $78.9 \%$ of patients with traumatic injury to peripheral nerves, reduced their NRS score by 3 points or more and $94.7 \%$ presented a $>$ reduction of the pain area. ${ }^{40}$ Other studies do not show a reduction of pain intensity with 5LP in cancer patients with persistent incisional pain ${ }^{30}$ or in patients with persistent inguinal postherniorrhaphy. ${ }^{39}$ Further studies are needed in other types of surgery for bring more information.

Regarding PHN, one meta-analysis, one systematic review, one Cochrane review, nine RCTs and three prospective studies have been found and presented positive results except in the Cochrane review. ${ }^{27,28,37,41-50}$ A recent meta-analysis ${ }^{48}$ conducted on 12 studies concludes that topical lidocaine is preferable to other topical drugs for PHN. It is the most effective and tolerable drug. It may restrain inflammatory factors of damaged tissue, that play an important role in pain. A systematic review ${ }^{49}$ concludes in the same direction in considering $5 \mathrm{LP}$ as a first-line treatment option for PHN in view of its efficacy and tolerability, a noticeable change since from the previous Cochrane study. ${ }^{50}$

Several RCTs present good results of lidocaine in PHN (Table 1). Indeed, a study realized on 24 patients 
Table 2 Randomized Clinical Trials with Topical Lidocaine in Neuropathic Pain Conditions

\begin{tabular}{|c|c|c|c|c|c|c|c|c|}
\hline Authors & Population & Design* & Treatment & $\begin{array}{l}\text { Sample } \\
\text { Size }\end{array}$ & $\begin{array}{c}\text { Maximum } \\
\text { Dose/Nb } \\
\text { of Plasters }\end{array}$ & $\begin{array}{c}\text { Follow- } \\
\text { Up } \\
\text { Weeks }\end{array}$ & $\begin{array}{l}\text { Concomitant } \\
\text { Medication }\end{array}$ & Primary Outcome \\
\hline $\begin{array}{l}\text { Pickering } \\
\text { et al, } 2019^{17}\end{array}$ & PSPP & Parallel & $\begin{array}{l}5 \% \text { Lidocaine plaster vs } \\
\text { placebo }\end{array}$ & $\begin{array}{l}24 \\
12\end{array}$ & 2 & 12 & Yes & $\begin{array}{l}\text { Dynamic mechanical } \\
\text { allodynia (DMA) diminished } \\
\text { of } \geq 30 \% \text { over } 3 \text { months } \\
(p=0.003)\end{array}$ \\
\hline $\begin{array}{l}\text { Palladini } \\
\text { et al, 2019 }\end{array}$ & PSPP & & $\begin{array}{l}5 \% \text { Lidocaine plaster vs } \\
\text { placebo }\end{array}$ & $\begin{array}{l}180 \\
183\end{array}$ & 3 & 12 & $\begin{array}{l}\text { "plaster only" } \\
\text { or "add-on" }\end{array}$ & $\begin{array}{l}\text { Numerical Rating Scale } \\
\text { (NRS): } p=N S\end{array}$ \\
\hline $\begin{array}{l}\text { Sansone } \\
\text { et al, } 2017^{38}\end{array}$ & PSPP & Single-blind & $\begin{array}{l}5 \% \text { Lidocaine plaster vs } \\
\text { Placebo }\end{array}$ & $\begin{array}{l}33 \\
30\end{array}$ & NR & 8 & NR & $\begin{array}{l}\text { NRS pain scores improved } \\
(p<0.01)\end{array}$ \\
\hline $\begin{array}{l}\text { Bischoff } \\
\text { et al, } 2013^{39}\end{array}$ & PSPP & & $\begin{array}{l}5 \% \text { Lidocaine plaster vs } \\
\text { placebo }\end{array}$ & $\begin{array}{l}21 \\
21\end{array}$ & 1 & 4 & Yes & $\begin{array}{l}\text { Summed Pain Intensity } \\
\text { (SPID): } p=N S\end{array}$ \\
\hline $\begin{array}{l}\text { Cheville } \\
\text { et al, } 2009^{30}\end{array}$ & PSPP & & $\begin{array}{l}5 \% \text { Lidocaine plaster vs } \\
\text { placebo }\end{array}$ & $\begin{array}{l}14 \\
14\end{array}$ & 3 & 8 & Yes & $\begin{array}{l}\text { Weekly pain intensity } \\
\text { ratings: } p=N S\end{array}$ \\
\hline $\begin{array}{l}\text { Kanai et al, } \\
2010^{42}\end{array}$ & $\begin{array}{l}\text { PHN } \\
\text { (ophthalmic) }\end{array}$ & & $\begin{array}{l}4 \% \text { Lidocaine eye drops } \\
\text { vs placebo }\end{array}$ & $\begin{array}{l}12 \\
12\end{array}$ & $\begin{array}{c}0.4 \mathrm{~mL} \\
\text { (single app.) }\end{array}$ & 2 & Yes & $\begin{array}{l}\text { Visual Analog Scale (VAS) } \\
\text { score decreased }(p<0.01) \text {. }\end{array}$ \\
\hline $\begin{array}{l}\text { Kanai et al, } \\
2009^{41}\end{array}$ & $\mathrm{PHN}$ & & $\begin{array}{l}8 \% \text { Lidocaine spray vs } \\
\text { placebo }\end{array}$ & $\begin{array}{l}12 \\
12\end{array}$ & $\begin{array}{l}0.1 \mathrm{~mL} / \text { single } \\
\text { spray, } 30 \\
\text { times }\end{array}$ & 1 & Yes & $\begin{array}{l}\text { VAS score decreased } \\
(p<0.01) .\end{array}$ \\
\hline $\begin{array}{l}\text { Binder et al, } \\
2009^{27}\end{array}$ & PHN & & $\begin{array}{l}5 \% \text { Lidocaine plaster vs } \\
\text { placebo }\end{array}$ & $\begin{array}{l}36 \\
35\end{array}$ & 3 & 2 & Yes & $\begin{array}{l}\text { Higher median time-to-exit } \\
(p=0.0398) \text { (per protocol). }\end{array}$ \\
\hline $\begin{array}{l}\text { Baron et al, } \\
2009^{28}\end{array}$ & $\mathrm{PHN}$ & $\begin{array}{l}\text { Open label, } \\
\text { active- } \\
\text { controlled, } \\
\text { non-inferiority } \\
\text { study }\end{array}$ & $\begin{array}{l}5 \% \text { Lidocaine plaster vs } \\
\text { pregabalin }\end{array}$ & $\begin{array}{l}50 \\
48\end{array}$ & 3 & 4 & No & $\begin{array}{l}\text { Greater responder rate } \\
(62.2 \% \text { vs } 46.5 \%) \text { (per } \\
\text { protocol). }\end{array}$ \\
\hline $\begin{array}{l}\text { Lin et al, } \\
2008^{45}\end{array}$ & $\mathrm{PHN}$ & Parallel & $\begin{array}{l}5 \% \text { Lidocaine plaster vs } \\
\text { placebo }\end{array}$ & $\begin{array}{l}23 \\
23\end{array}$ & 1 & 2 days & Yes & $\begin{array}{l}\text { Pain intensity reduction at } \\
\text { rest }(p=0.005) \text { and during } \\
\text { movement }(p=0.007)\end{array}$ \\
\hline $\begin{array}{l}\text { Galer et al, } \\
2002^{47}\end{array}$ & $\mathrm{PHN}$ & Parallel & $\begin{array}{l}5 \% \text { Lidocaine plaster vs } \\
\text { placebo }\end{array}$ & $\begin{array}{l}67 \\
29\end{array}$ & NR & 3 & NR & $\begin{array}{l}\text { Neuropathic Pain Scale } \\
\text { (NPS) scores reductions } \\
(p=0.043) \text {. }\end{array}$ \\
\hline $\begin{array}{l}\text { Galer et al, } \\
1999^{46}\end{array}$ & PHN & & $\begin{array}{l}5 \% \text { Lidocaine plaster vs } \\
\text { placebo }\end{array}$ & $\begin{array}{l}16 \\
16\end{array}$ & 3 & 4 & NR & $\begin{array}{l}\text { Median-time to-exit } \\
\text { significantly higher } \\
(p<0.001)\end{array}$ \\
\hline $\begin{array}{l}\text { Rowbotham } \\
\text { et al, } 1996^{44}\end{array}$ & $\mathrm{PHN}$ & & $\begin{array}{l}5 \% \text { Lidocaine plaster vs } \\
\text { placebo }\end{array}$ & $\begin{array}{l}35 \\
35\end{array}$ & 3 & 4 & Yes & $\begin{array}{l}\text { VAS scores reductions } \\
\text { from } 4 h \text { to } 12 h(p<0.05) \text {. }\end{array}$ \\
\hline $\begin{array}{l}\text { Rowbotham } \\
\text { et al, } 1995^{43}\end{array}$ & $\mathrm{PHN}$ & & $\begin{array}{l}5 \% \text { Lidocaine gel vs } \\
\text { placebo }\end{array}$ & $\begin{array}{l}20 \\
19\end{array}$ & $\begin{array}{l}200- \\
800 \mathrm{~cm}^{2} \text { of } \\
\text { skin } \\
\text { covered }\end{array}$ & 3 & Yes & $\begin{array}{l}\text { VAS scores reductions in } \\
\text { torso-limb group at } 8 \mathrm{~h} \text { and } \\
24 \mathrm{~h}(\mathrm{p}<0.05)\end{array}$ \\
\hline $\begin{array}{l}\text { Baron et al, } \\
2009^{28}\end{array}$ & DPN & $\begin{array}{l}\text { Open label, } \\
\text { active- } \\
\text { controlled, } \\
\text { non-inferiority } \\
\text { study }\end{array}$ & $\begin{array}{l}5 \% \text { Lidocaine plaster vs } \\
\text { pregabalin }\end{array}$ & $\begin{array}{l}107 \\
106\end{array}$ & 4 & 4 & No & $\begin{array}{l}\text { Comparable response rate } \\
\text { (66.7\% vs } 69.1 \%) \text {. }\end{array}$ \\
\hline
\end{tabular}

(Continued) 
Table 2 (Continued).

\begin{tabular}{|c|c|c|c|c|c|c|c|c|}
\hline Authors & Population & Design* & Treatment & $\begin{array}{c}\text { Sample } \\
\text { Size }\end{array}$ & $\begin{array}{c}\text { Maximum } \\
\text { Dose/Nb } \\
\text { of Plasters }\end{array}$ & $\begin{array}{l}\text { Follow- } \\
\text { Up } \\
\text { Weeks }\end{array}$ & $\begin{array}{l}\text { Concomitant } \\
\text { Medication }\end{array}$ & Primary Outcome \\
\hline $\begin{array}{l}\text { Moghtaderi } \\
\text { et al, } 2009^{59}\end{array}$ & $\begin{array}{l}\text { Carpal } \\
\text { tunnel } \\
\text { syndrome }\end{array}$ & $\begin{array}{l}\text { Parallel, open- } \\
\text { label, active- } \\
\text { controlled }\end{array}$ & $\begin{array}{l}2.5 \% \text { lidocaine plus } \\
2.5 \% \text { prilocaine vs } \\
\text { methylprednisolone } \\
\text { acetate } 40 \mathrm{mg}\end{array}$ & $\begin{array}{l}35 \\
35\end{array}$ & $\begin{array}{l}\text { Daily app. vs } \\
\text { one } \\
\text { injection }\end{array}$ & 4 & NR & $\begin{array}{l}\text { Pain intensity diminution in } \\
\text { both groups }(p<0.001) \text {. }\end{array}$ \\
\hline $\begin{array}{l}\text { Nalamachu } \\
\text { et al, } 2006^{57}\end{array}$ & $\begin{array}{l}\text { Carpal } \\
\text { tunnel } \\
\text { syndrome }\end{array}$ & $\begin{array}{l}\text { Parallel, open } \\
\text { label, active- } \\
\text { controlled }\end{array}$ & $\begin{array}{l}5 \% \text { Lidocaine plaster vs } \\
1 \% \text { lidocaine injection, } \\
\text { methylprednisolone } \\
\text { acetate }\end{array}$ & $\begin{array}{l}20 \\
20\end{array}$ & $\begin{array}{l}\text { I vs } 0.5 \mathrm{cc} \text {, } \\
40 \mathrm{mg}\end{array}$ & 4 & NR & $\begin{array}{l}\text { Worst pain, average pain, } \\
\text { and pain "right now" } \\
\text { diminution in both groups } \\
(p<0.05)\end{array}$ \\
\hline $\begin{array}{l}\text { Nalamachu } \\
\text { et al, } 2006^{58}\end{array}$ & $\begin{array}{l}\text { Carpal } \\
\text { tunnel } \\
\text { syndrome }\end{array}$ & $\begin{array}{l}\text { Parallel, open- } \\
\text { label, active- } \\
\text { controlled }\end{array}$ & $\begin{array}{l}5 \% \text { Lidocaine plaster vs } \\
\text { naproxen } 1000 \mathrm{mg}\end{array}$ & $\begin{array}{l}52 \\
48\end{array}$ & 3 & 6 & NR & $\begin{array}{l}\text { Average Pain Intensity (API) } \\
\text { scores reduced } 5 L P \\
(p<0.000 I) \text { and naproxen } \\
(p=0.0004) \\
\text { Difference between } \\
\text { treatments ( } P=N S)\end{array}$ \\
\hline
\end{tabular}

Note: *All studies are randomized, double blind, crossover and versus (vs) placebo, unless specified.

Abbreviations: PSPP, posttraumatic/post-surgical persistent pain; PHN, postherpetic neuralgia; DPN, diabetic peripheral neuropathy; NR, not reported; No, no concomitant medication.

with ophthalmic PHN who received 4\% lidocaine eye drops or placebo demonstrates a significant decrease in the visual analog scale (VAS) score in the eye (baseline: $5.9 \pm 2.2 \mathrm{~cm} ; 15$ minutes after eye drops: $0.9 \pm 1.8 \mathrm{~cm}$, mean $\pm \mathrm{SD} ; \mathrm{p}<0.01$ ) with a significant mean change between lidocaine and placebo group. ${ }^{42}$ In another study, 8\% lidocaine pump spray is used and compared to placebo in PHN patients: a greater decrease in VAS score was observed in the lidocaine group $(6.1 \pm 1.7 \mathrm{~cm}$ before spray to $2.3 \pm 2.5 \mathrm{~cm}$ at 15 -minute post-spray; $\mathrm{p}<0.01)$ and placebo group $(6.1 \pm 1.7 \mathrm{~cm}$ to $5.7 \pm 1.6$; $p<0.05)$. The mean change between lidocaine and placebo is significant $(\mathrm{p}<0.01) .{ }^{41}$ Binder et al consider that $5 \mathrm{LP}$ is a valuable treatment option for patients with PHN with a median time-to-exit of 14.0 [3-14] in the lidocaine group and 6.0 [1-14] in the placebo group $(\mathrm{p}=0.0398) .{ }^{27}$ An open label randomized non-inferiority study between 5LP and pregabalin follow-up for 4 weeks shows, after stratification by type of NP, more patients' responders to 5LP than to pregabalin in PHN patients $\left(62.2 \%\right.$ vs $46.5 \%$, per protocol set). ${ }^{28}$ In another randomized study, the effectiveness of 5LP compared to placebo has been demonstrated with differences of mean reduction of pain intensity between groups of 14.7 (4.724.8, $p=0.005$ ) in favor of $5 \mathrm{LP}^{45}$ Four older RCTs concluded with similar positive results in favor of 5LP and are described in Table $1 .^{43,44,46,47}$
Regarding prospective studies, a total of 249 patients are followed in 2 long-term studies (treatment $\geq 12$ months with 5LP) and demonstrate effectiveness of 5LP by maintained reductions in pain intensity associated with a good tolerability in PHN patients. ${ }^{51,52}$ Finally, an open-label non-randomized prospective study that aimed to determine the impact of 5LP on pain quality associated with chronic pain using the Neuropathic Pain Scale (NPS) describes, in a subgroup analysis, a numerical advantage for all 4 NPS composite measures for the PHN patients. ${ }^{53}$

Considering DPN, two systematic reviews and metaanalysis, one RCT and one prospective study have been selected, all of them showing positive results. ${ }^{28,54-56}$ Very few studies comparing topical lidocaine to other agents exist for DNP. A systematic review and meta-analysis on pharmacological therapy for DPN, shows that 5LP had the highest probability of $30 \%$ reduction compared with placebo $(1.84,[1.39,2.21]) .{ }^{54}$ Another review ${ }^{55}$ concluded that limited evidence suggested 5LP provided comparable pain reduction to amitriptyline, capsaicin, pregabalin and gabapentin in DNP and may be associated with fewer AEs. The authors correctly acknowledge that the few small included trials provide limited evidence, and this should be taken into account when interpreting the results. Only one open-label non-inferiority study realized in 161 DPN patients showed comparable pain relief in the lidocaine and pregabalin groups $(67 \%$ vs $69 \%$, respectively); 
however, a better quality of life was observed in the lidocaine group (Table 1). ${ }^{28}$ Regarding prospective openlabel study, Barbano et al describe significant improvement in pain and quality-of-life during 3 weeks of treatment. $^{56}$

For carpal tunnel syndrome, only three randomized and open-label studies focused on carpal tunnel syndrome with no statistical difference between treatments. However, these studies reported pain relief in both groups suggesting that topical lidocaine may be effective and safe in treatment of carpal tunnel syndrome (Table 1). ${ }^{57-59}$ In two pilot studies, 5LP was compared to an injection of lidocaine/ methylprednisolone for 4 weeks in 40 randomized patients $^{57}$ and was compared to naproxen (500 mg x 2/d) for 6 weeks in 100 randomized patients. ${ }^{58}$ The last trial used prilocaine+lidocaine cream compared to an injection of methylprednisolone (40mg) for 4 weeks in 65 randomized patients. ${ }^{59}$ Studies do not report statistically significant difference between treatments, but this difference was often not evaluated and further studies are warranted.

\section{Musculoskeletal Pain}

Musculoskeletal diseases are defined as a group of diseases that affect different structures of the musculoskeletal system (nerves, tendons, muscles, joints, ligaments, bones, blood vessels) and supporting structures such as intervertebral discs. ${ }^{60,61}$ Some studies have reported that musculoskeletal diseases and pain considerably contribute to reduced productivity and poorer quality of work, increase dependence levels and demands on health systems, especially considering musculoskeletal aging. ${ }^{62,63}$ CLBP is one of the most prevalent musculoskeletal disorders and affects $70 \%$ to $85 \%$ of the adult population. ${ }^{64}$ One year after the onset of low back pain, $45 \%$ to $75 \%$ of patients still experience pain, ${ }^{65}$ representing important expenses in health care. $^{64}$

A total of two RCTs and three prospective studies focused on CLBP have been found with positive results. ${ }^{53,66-69}$ Considering OA, only one open-label RCT and three prospective studies have been selected, one study did not show any difference in effectiveness/tolerability, while the other prospective studies did show positive results (Table 3 ). ${ }^{57-59,70}$

In CLBP, the majority of studies are open-label and uncontrolled $^{53,68,69}$; only two studies are $\mathrm{RCTs}^{66,67}$ and used different tools to measure pain (Brief Pain Inventory, the Visual Analog Scale, the Short-Form McGill Pain Questionnaire, and the Neuropathic Pain Scale) (Table 1).
Hashmi et al demonstrated a statistically significant reduction in pain in both groups (5LP vs placebo) without difference between the treatment groups. ${ }^{66}$ In an open-label study, the lidocaine plaster induced a statistically significant reduction in pain with QOL and depression improvement. ${ }^{69}$ One of these open-label CLBP studies showed in 29 patients an improvement of composite measures of $\mathrm{NP}^{53}$ and suggested that lidocaine plaster may be used as an addon therapy. Functional magnetic resonance imaging studies after 5LP treatment reported a decrease in pain-related brain activity in the medial prefrontal cortex compared to baseline. ${ }^{66,68}$ Although these studies are limited, CLBP is a real cause of disability and of opioid use in the US, suggesting the need to find other alternatives such as lidocaine plasters combined with appropriate oral therapies. ${ }^{18}$ In the context of the opioid crisis, general recommendations favor opioid-sparing analgesia. Topical treatments have an increasing role to play in analgesia, given their good benefit-risk balance and the possibility to diminish the use of step 2 and 3 opioids.

Concerning OA, topical analgesics, including NSAIDs and capsaicin, are recommended in guidelines for OA pain, ${ }^{5,60}$ but topical lidocaine is poorly documented. Only one open-label RCT compares the effectiveness of 5LP with celecoxib in the treatment of OA-related knee pain. $^{70}$ In this study, no difference in effectiveness and tolerability was found between both treatments (WOMAC OA subscale scores: 5LP, 12.087; celecoxib $200 \mathrm{mg} / \mathrm{d}, 12.514)$ and mean rates of change over time (baseline to week $2,-1.5916$ vs -1.6513 per week; weeks $2-6,-0.0168$ vs -0.119 per week; weeks $6-12,-0.1818$ vs -0.1579 per week). Furthermore, three open-label prospective studies tried to evaluate the efficacy of lidocaine plasters in a total of 257 patients with knee OA. Burch et al obtained significant improvement in pain intensity, WOMAC (Western Ontario and McMaster Universities Arthritis Index) score and QOL in 137 patients with OA of the knee with an incomplete response to analgesic therapy. ${ }^{71}$ Similar results are reported in another study realized in 20 patients with inadequate relief of pain. ${ }^{72}$ Finally, a significant improvement in all composite measures of the Neuropathic Pain Scale is demonstrated both in monotherapy and add-on therapy. ${ }^{73}$ Although lidocaine is not indicated for $\mathrm{OA}$, the results of these open-label studies suggest that lidocaine plaster may offer an option to patients not relieved by usual treatments. Further randomized and controlled trials are needed to confirm this hypothesis. 
Table 3 Randomized Clinical Trials with Topical Lidocaine in Musculoskeletal Pain

\begin{tabular}{|c|c|c|c|c|c|c|c|c|}
\hline Authors & Population & Design* & Treatment & $\begin{array}{c}\text { Sample } \\
\text { Size }\end{array}$ & $\begin{array}{l}\text { Maximum } \\
\text { Dose/Nb } \\
\text { of Plasters }\end{array}$ & $\begin{array}{l}\text { Follow- } \\
\text { Up } \\
\text { Weeks }\end{array}$ & $\begin{array}{l}\text { Concomitant } \\
\text { Medication }\end{array}$ & Primary Outcome \\
\hline $\begin{array}{l}\text { Castro } \\
\text { and } \\
\text { Dent, } \\
2017^{67}\end{array}$ & CLBP & Parallel & $\begin{array}{l}5 \% \text { Lidocaine } \\
\text { plaster (Rx) vs } \\
3.6 \% \text { lidocaine } \\
\text { plaster+I,25\% } \\
\text { menthol } \\
\text { (OTC) vs } \\
\text { placebo }\end{array}$ & NR & NR & NR & NR & $\begin{array}{l}\text { Non-inferiority of OTC } \\
\text { compared with Rx for } \\
\text { efficacy, side effects and } \\
\text { quality of life. Versus } \\
\text { placebo, OTC proved } \\
\text { superiority for efficacy, } \\
\text { general activity and normal } \\
\text { work }\end{array}$ \\
\hline $\begin{array}{l}\text { Hashmi } \\
\text { et al, } \\
2012^{66}\end{array}$ & CLBP & Parallel & $\begin{array}{l}5 \% \text { Lidocaine } \\
\text { plaster vs } \\
\text { placebo }\end{array}$ & $\begin{array}{l}15 \\
15\end{array}$ & NR & 2 & NR & $\begin{array}{l}\text { Pain intensity, sensory and } \\
\text { affective qualities of pain or } \\
\text { pain related brain } \\
\text { activation at any time point } \\
(\mathrm{p}=\mathrm{NS})\end{array}$ \\
\hline $\begin{array}{l}\text { Kivitz } \\
\text { et al, } \\
2008^{70}\end{array}$ & OA & $\begin{array}{l}\text { Parallel, } \\
\text { open } \\
\text { label, } \\
\text { active- } \\
\text { controlled }\end{array}$ & $\begin{array}{l}5 \% \text { Lidocaine } \\
\text { plaster vs } \\
\text { celecoxib } \\
200 \mathrm{mg}\end{array}$ & $\begin{array}{l}69 \\
74\end{array}$ & $1-1 / 3$ & 12 & Yes & $\begin{array}{l}\text { WOMAC OA subscale } \\
\text { scores and mean rates of } \\
\text { change over time }(p=N S)\end{array}$ \\
\hline
\end{tabular}

Note: *All studies are randomized, double blind, crossover and versus (vs) placebo, unless specified.

Abbreviations: CLBP, chronic low back pain; OA, osteoarthritis pain; NR, not reported; No, no concomitant medication.

\section{Tolerability and Safety}

Topical lidocaine is generally reported as safe and with a good tolerability. The risk of AEs is limited because little systemic diffusion reduces the risk of potential interactions with concomitant medications. The most frequently reported AEs are found at the application site, including skin reactions (itch, erythema, burning, rash, edema and dermatitis). These are often mild and spontaneously resolve within a few minutes to hours after plaster removal. ${ }^{11,24,74}$ Studies showed 5LP is well tolerated in long-term use with sustained pain relief for different types of NP. ${ }^{17,37}$ However, hepatic or renal disease may occasionally need dose adjustment in order to avoid toxic blood lidocaine concentrations, especially in patients with mild to moderate or hepatic impairment. Potential risks of systemic effects (respiratory distress, seizures, dizziness, loss of consciousness, drowsiness and cardiac arrest) ${ }^{11,74}$ could occur in patients treated also with other local anesthetics or Class I antiarrhythmic drugs (eg, mexiletine and tocainide). For DPN and PHN, lidocaine was reported to be better tolerated than systemic pregabalin (AEs rate, $5.8 \%$ with lidocaine-medicated plaster, versus $41.2 \%$ with oral pregabalin). ${ }^{28}$

\section{Discussion}

Lidocaine is usually recommended as a first-line drug but is underutilized in PHN patients. ${ }^{75}$ Instead, second- or third-line treatments (ie, opiates and capsaicin) or NSAIDs (which are not recommended and have been shown in a meta-analysis to be ineffective for $\mathrm{NP}^{76}$ ) are frequently used as the initial treatment. ${ }^{75}$ Gudin et al report that lidocaine patches were only used initially in $8 \%$ of PHN patients, while $32 \%$ of them received no treatment; opioids were the most common initial treatment (22\%) followed by gabapentin (15\%) and NSAIDs $(9 \%)$. Those treatments that do not follow official recommendations cause excessive health-care costs, and increase the risk of opioid overuse. ${ }^{75}$ In DPN, pregabalin and duloxetine are the only medications approved by the FDA. Based on current practice guidelines, these medications, with gabapentin and amitriptyline, should be considered for initial treatment. Second-line and third-line therapies include opioidlike medications (tramadol and tapentadol), venlafaxine, desvenlafaxine, and topical agents (lidocaine patches and capsaicin cream). ${ }^{77}$ Lidocaine patch may be an useful therapy for the treatment of pain relief in DPN. ${ }^{78}$

One of the advantages of topical lidocaine is that it avoids the systemic route of drug metabolism compared to 
other routes, especially in persons with comorbidities. The traditional route of administration in pain medication for patients with chronic or acute pain is oral therapy, although this may be limited in a number of conditions (comorbidities, end-organ damage, AEs, and drug interactions). ${ }^{79,80}$ The oral route exhibits a variety of potential AEs, especially in vulnerable patients and older patients with comorbidities and polypharmacy. ${ }^{81,82}$ Indeed, pharmacokinetic and pharmacodynamic age-related changes (decreased absorption, impaired distribution, hepatic metabolism and renal clearance) increase the risk of multiple disorders, including gastrointestinal disorders, confusion, sedation and memory loss often causing poor compliance in geriatric populations. ${ }^{81}$ Guidelines in NP treatment have been published and recommended 5LP as a possible first-line treatment for frail and elderly patients. ${ }^{4}$ A review of various studies showed effectiveness in elderly patients with polypharmacy. ${ }^{83}$ The cognitive deficits widely observed in NP patients taking antidepressants are not found with 5LP. In this vulnerable population, topical pain management is an interesting alternative to alleviate pain and maintain cognitive integrity. ${ }^{81}$

Topical agents offer other advantages compared to oral analgesics, including avoidance of hepatic first-pass metabolism, less fluctuation in drug levels, a lower total systemic daily dose and the possibility to be more specific with a treatment directly on the affected area. ${ }^{84}$ Another advantage is the possibility of combining it with other systemic drugs in order to achieve an additive effect without systemic drug interaction or additional side effects. ${ }^{85}$ In addition to its efficacy and safety, local treatment with lidocaine is easy to administer and displays a good patient compliance. The possibility of coupling up to three plasters or trimming the plaster to fit different body sites allows a good adaptation to the particular pain site. A clinical trial ${ }^{17}$ clearly shows excellent patient compliance and efficacy in pain following knee arthroplasty.

To our knowledge, the efficacy of pain relief by lidocaine has not been established in large studies in children. ${ }^{86-89}$ A recent prospective study supports the efficacy of 5LP in children and adolescents with localized neuropathic pain as part of a multidisciplinary pain approach with good tolerability and safety. ${ }^{90}$ However, caution is needed because of the immaturity of some neural systems and of pain pathways undergoing a series of transitional functional states before reaching maturity. ${ }^{91}$ Caution is also needed because of the theoretic risk of systemic absorption of lidocaine and its severe toxic effects in case of accidental mucosal absorption (by rubbing the patch on the eye or sucking on the mixture).

Topical agents have however a few drawbacks, including poor product adhesion (1.8\% lidocaine topical system presents superior adhesion profile than 5LP) and an application on an area with good skin integrity to avoid risk of toxicity. A variety of formulations have been studied but not commercialized worldwide and not standardized, with prescription in some countries or OTC in others., 9,92 Studies are usually of short duration with a small number of participants, not double-blind, and with a poor description of the placebo when there is one. The type of pain is often limited to PHN or DPN, while the main cause of NP in real life is post-surgery $\mathrm{NP}^{31}$

Practice Guidelines on topical lidocaine are regularly published by manufacturers and researchers. ${ }^{9,12,75,93}$ These may be summarized in the 10 following points:

1. Topical lidocaine should be used as directed by health care professionals and according to directions of the manufacturer.

2. Over the counter 4\% lidocaine patch is a medication and should be used accordingly.

3. Allergic adverse events may occur, and drug interactions should be prevented.

4. Five percent lidocaine patch may be applied to the painful area for 12 hours per day with a 12-hour break.

5. The patch should cover the whole painful area, especially the target zone, if any.

6. It must fit the size of the painful area; it is possible to cut before peeling off the release liner.

7. The maximum dose is three patches a day, 12 in a 24-hour period.

8. Topical lidocaine is applied only to intact skin, not to open wounds, burns, or broken or inflamed skin, avoiding contact with the eyes.

9. Any burning sensation or local irritation requires removal of the patch until irritation subsides.

10. It should be used with caution in severe hepatic or cardiac disease.

In conclusion, topical lidocaine is widely used in current practice for a variety of pain conditions. Its limited absorption and relative lack of systemic adverse events is an attractive analgesic option for a number of vulnerable patients. Topical lidocaine has been approved by health authorities for the treatment of post-herpetic neuralgia in a number of countries, and studies present some degree of evidence of its efficacy and safety in PSPP, DPN, carpal tunnel syndrome, 
CLBP and OA. Health authorities worldwide endorse opioidsparing analgesia and topical treatments have an increasing role to play in this context, with their very favorable benefitrisk balance. Topical lidocaine may be a great alternative alone or in addition to systemic drugs and nonpharmacological approaches for an optimized pain management and in multimodal analgesia.

\section{Author Contributions}

All authors made a significant contribution to the work reported, whether that is in the conception, study design, execution, acquisition of data, analysis and interpretation, or in all these areas; took part in drafting, revising or critically reviewing the article; gave final approval of the version to be published; have agreed on the journal to which the article has been submitted; and agree to be accountable for all aspects of the work.

\section{Disclosure}

The authors report no conflicts of interest in this work.

\section{References}

1. Brennan MJ. The effect of opioid therapy on endocrine function. Am J Med. 2013;126(3 Suppl 1):S12-18. doi:10.1016/j. amjmed.2012.12.001

2. Cohen SP, Mao J. Neuropathic pain: mechanisms and their clinical implications. BMJ. 2014;348:f7656. doi:10.1136/bmj.f7656

3. Dworkin RH, O'Connor AB, Audette J, et al. Recommendations for the pharmacological management of neuropathic pain: an overview and literature update. Mayo Clin Proc. 2010;85(3 Suppl):S3-14. doi: $10.4065 / \mathrm{mcp} .2009 .0649$

4. Finnerup NB, Attal N, Haroutounian S, et al. Pharmacotherapy for neuropathic pain in adults: a systematic review and meta-analysis. Lancet Neurol. 2015;14(2):162-173. doi:10.1016/S1474-4422(14)70251-0

5. Centre for Clinical Practice at NICE (UK). Neuropathic pain: the pharmacological management of neuropathic pain in adults in non-specialist settings. UK: National Institute for Health and Care Excellence; 2013. Available from: http://www.ncbi.nlm.nih.gov/ books/NBK266257/. Accessed April 15, 2021.

6. Moisset X, Bouhassira D, Avez Couturier J, et al. Pharmacological and non-pharmacological treatments for neuropathic pain: systematic review and French recommendations. Rev Neurol (Paris). 2020;176 (5):325-352. doi:10.1016/j.neurol.2020.01.361

7. Deng Y, Luo L, Hu Y, Fang K, Liu J. Clinical practice guidelines for the management of neuropathic pain: a systematic review. BMC Anesthesiol. 2016;16(1):12. doi:10.1186/s12871-015-0150-5

8. Pickering G, Marcoux M, Chapiro S, et al. An algorithm for neuropathic pain management in older people. Drugs Aging. 2016;33 (8):575-583. doi:10.1007/s40266-016-0389-7

9. de León-Casasola OA, Mayoral V. The topical 5\% lidocaine medicated plaster in localized neuropathic pain: a reappraisal of the clinical evidence. J Pain Res. 2016;9:67-79. doi:10.2147/JPR. S99231

10. Gordh T, Gordh TE, Lindqvist K, Warner DS. Lidocaine: the origin of a modern local anesthetic 1949. Anesthesiology. 2010;113 (6):1433-1437. doi:10.1097/ALN.0b013e3181 fcef48
11. LIDODERM patch prescribing information. Malvern PA: Endo Pharmaceuticals Inc; 2015. Available from: https://www.accessdata.fda. gov/drugsatfda_docs/label/2015/020612s012lbl.pdf. Accessed April 15, 2021.

12. Versatis $700 \mathrm{mg}$ medicated plaster - summary of product characteristics $(\mathrm{SmPC})$ - (emc). Available from: https://www.medicines.org. uk/emc/product/290/smpc\#gref. Accessed April 15, 2021.

13. Gammaitoni AR, Alvarez NA, Galer BS. Safety and tolerability of the lidocaine patch $5 \%$, a targeted peripheral analgesic: a review of the literature. J Clin Pharmacol. 2003;43(2):111-117. doi:10.1177/ 0091270002239817

14. Hermanns H, Hollmann MW, Stevens MF, et al. Molecular mechanisms of action of systemic lidocaine in acute and chronic pain: a narrative review. $B r \quad J$ Anaesth. 2019;123(3):335-349. doi:10.1016/j.bja.2019.06.014

15. Meier T, Wasner G, Faust M, et al. Efficacy of lidocaine patch $5 \%$ in the treatment of focal peripheral neuropathic pain syndromes: a randomized, double-blind, placebo-controlled study. Pain. 2003;106(1-2):151-158. doi:10.1016/s0304-3959(03)00317-8

16. Rehm S, Binder A, Baron R. Post-herpetic neuralgia: 5\% lidocaine medicated plaster, pregabalin, or a combination of both? A randomized, open, clinical effectiveness study. Curr Med Res Opin. 2010;26(7):1607-1619. doi:10.1185/03007995.2010.483675

17. Pickering G, Voute M, Macian N, Ganry H, Pereira B. Effectiveness and safety of $5 \%$ lidocaine-medicated plaster on localized neuropathic pain after knee surgery: a randomized, double-blind controlled trial. Pain. 2019;160(5):1186-1195. doi:10.1097/j.pain.0000000000001502

18. Baron R, Binder A, Attal N, Casale R, Dickenson AH, Treede R-D. Neuropathic low back pain in clinical practice. Eur J Pain. 2016;20 (6):861-873. doi:10.1002/ejp.838

19. Buksnys T, Armstrong N, Worthy G, et al. Systematic review and network meta-analysis of the efficacy and safety of lidocaine $700 \mathrm{mg}$ medicated plaster vs. pregabalin. Curr Med Res Opin. 2020;36 (1):101-115. doi:10.1080/03007995.2019.1662687

20. Derry S, Wiffen PJ, Moore RA, Quinlan J. Topical lidocaine for neuropathic pain in adults. Cochrane Database Syst Rev. 2014;(7): CD010958. doi:10.1002/14651858.CD010958.pub2

21. Derry S, Wiffen PJ, Kalso EA, et al. Topical analgesics for acute and chronic pain in adults - an overview of Cochrane reviews. Cochrane Database Syst Rev. 2017;5:CD008609. doi:10.1002/14651858. CD008609.pub2

22. Demant DT, Lund K, Finnerup NB, et al. Pain relief with lidocaine $5 \%$ patch in localized peripheral neuropathic pain in relation to pain phenotype: a randomised, double-blind, and placebo-controlled, phenotype panel study. Pain. 2015;156(11):2234-2244. doi:10.1097/j. pain.000000000000266

23. Ho K-Y, Huh BK, White WD, Yeh -C-C, Miller EJ. Topical amitriptyline versus lidocaine in the treatment of neuropathic pain. Clin J Pain. 2008;24(1):51-55. doi:10.1097/AJP.0b013e318156db26

24. White WT, Patel N, Drass M, Nalamachu S. Lidocaine patch 5\% with systemic analgesics such as gabapentin: a rational polypharmacy approach for the treatment of chronic pain. Pain Med. 2003;4 (4):321-330. doi:10.1111/j.1526-4637.2003.03045.x

25. van Hecke O, Austin SK, Khan RA, Smith BH, Torrance N. Neuropathic pain in the general population: a systematic review of epidemiological studies. Pain. 2014;155(4):654-662. doi:10.1016/j. pain.2013.11.013

26. Treede R-D, Jensen TS, Campbell JN, et al. Neuropathic pain: redefinition and a grading system for clinical and research purposes. Neurology. 2008;70(18):1630-1635. doi:10.1212/01. wnl.0000282763.29778.59

27. Binder A, Bruxelle J, Rogers P, Hans G, Bösl I, Baron R. Topical 5\% lidocaine (lignocaine) medicated plaster treatment for post-herpetic neuralgia: results of a double-blind, placebo-controlled, multinational efficacy and safety trial. Clin Drug Investig. 2009;29(6):393-408. doi:10.2165/00044011-200929060-00003 
28. Baron R, Mayoral V, Leijon G, Binder A, Steigerwald I, Serpell M. $5 \%$ lidocaine medicated plaster versus pregabalin in post-herpetic neuralgia and diabetic polyneuropathy: an open-label, non-inferiority two-stage RCT Study. Curr Med Res Opin. 2009;25 (7):1663-1676. doi:10.1185/03007990903047880

29. Sonohata M, Tsuruta $\mathrm{T}$, Mine $\mathrm{H}$, et al. Clinical characteristics of neuropathic pain in patients with carpal tunnel syndrome. Hand Surg. 2014;19(1):43-48. doi:10.1142/S0218810414500087

30. Cheville AL, Sloan JA, Northfelt DW, et al. Use of a lidocaine patch in the management of postsurgical neuropathic pain in patients with cancer: a Phase III double-blind crossover study (N01CB). Support Care Cancer. 2009;17(4):451-460. doi:10.1007/s00520-008-0542-x

31. Fornasari D. Pharmacotherapy for neuropathic pain: a review. Pain Ther. 2017;6(Suppl 1):25-33. doi:10.1007/s40122-017-0091-4

32. Dualé C, Ouchchane L, Schoeffler P, Dubray C; EDONIS Investigating Group. Neuropathic aspects of persistent postsurgical pain: a French multicenter survey with a 6-month prospective follow-up. $J$ Pain. 2014;15(1):24.e1-24.e20. doi:10.1016/j. jpain.2013.08.014

33. Ammitzbøll G, Andersen KG, Bidstrup PE, et al. Effect of progressive resistance training on persistent pain after axillary dissection in breast cancer: a randomized controlled trial. Breast Cancer Res Treat. 2020;179(1):173-183. doi:10.1007/s10549-019-05461-z

34. Dualé C, Guastella V, Morand D, et al. Characteristics of the neuropathy induced by thoracotomy: a 4-month follow-up study with psychophysical examination. Clin J Pain. 2011;27(6):471-480. doi:10.1097/AJP.0b013e31820e12d4

35. Aasvang EK, Gmaehle E, Hansen JB, et al. Predictive risk factors for persistent postherniotomy pain. Anesthesiology. 2010;112 (4):957-969. doi:10.1097/ALN.0b013e3181d31ff8

36. Wilder-Smith $\mathrm{CH}$, Hill LT, Laurent S. Postamputation pain and sensory changes in treatment-naive patients: characteristics and responses to treatment with tramadol, amitriptyline, and placebo. Anesthesiology. 2005;103(3):619-628. doi:10.1097/00000542200509000-00027

37. Palladini M, Boesl I, Koenig S, Buchheister B, Attal N. Lidocaine medicated plaster, an additional potential treatment option for localized post-surgical neuropathic pain: efficacy and safety results of a randomized, placebo-controlled trial. Curr Med Res Opin. 2019;35 (5):757-766. doi:10.1080/03007995.2019.1565709

38. Sansone P, Passavanti MB, Fiorelli A, et al. Efficacy of the topical $5 \%$ lidocaine medicated plaster in the treatment of chronic post-thoracotomy neuropathic pain. Pain Manag. 2017;7 (3):189-196. doi:10.2217/pmt-2016-0060

39. Bischoff JM, Petersen M, Uçeyler N, Sommer C, Kehlet H, Werner MU. Lidocaine patch $(5 \%)$ in treatment of persistent inguinal postherniorrhaphy pain: a randomized, double-blind, placebo-controlled, crossover trial. Anesthesiology. 2013;119 (6):1444-1452. doi:10.1097/ALN.0b013e3182a2a243

40. Correa-Illanes G, Roa R, Piñeros JL, Calderón W. Use of 5\% lidocaine medicated plaster to treat localized neuropathic pain secondary to traumatic injury of peripheral nerves. Local Reg Anesth. 2012;5:47-53. doi:10.2147/LRA.S31868

41. Kanai A, Segawa Y, Okamoto T, Koto M, Okamoto H. The analgesic effect of a metered-dose $8 \%$ lidocaine pump spray in posttraumatic peripheral neuropathy: a pilot study. Anesth Analg. 2009;108 (3):987-991. doi:10.1213/ane.0b013e31819431aa

42. Kanai A, Okamoto T, Suzuki K, Niki Y, Okamoto H. Lidocaine eye drops attenuate pain associated with ophthalmic postherpetic neuralgia. Anesth Analg. 2010;110(5):1457-1460. doi:10.1213/ ANE.0b013e3181d5adaf

43. Rowbotham MC, Davies PS, Fields HL. Topical lidocaine gel relieves postherpetic neuralgia. Ann Neurol. 1995;37(2):246-253. doi:10.1002/ana.410370216
44. Rowbotham MC, Davies PS, Verkempinck C, Galer BS. Lidocaine patch: double-blind controlled study of a new treatment method for post-herpetic neuralgia. Pain. 1996;65(1):39-44. doi:10.1016/03043959(95)00146-8

45. Lin P-L, Fan S-Z, Huang C-H, et al. Analgesic effect of lidocaine patch $5 \%$ in the treatment of acute herpes zoster: a Double-Blind and Vehicle-Controlled Study. Reg Anesth Pain Med. 2008;33 (4):320-325. doi:10.1016/j.rapm.2007.02.015

46. Galer BS, Rowbotham MC, Perander J, Friedman E. Topical lidocaine patch relieves postherpetic neuralgia more effectively than a vehicle topical patch: results of an Enriched Enrollment Study. Pain. 1999;80(3):533-538. doi:10.1016/S0304-3959(98)00244-9

47. Galer BS, Jensen MP, Ma T, Davies PS, Rowbotham MC. The lidocaine patch $5 \%$ effectively treats all neuropathic pain qualities: results of a randomized, double-blind, vehicle-controlled, 3-week efficacy study with use of the neuropathic pain scale. Clin J Pain. 2002;18(5):297-301. doi:10.1097/00002508-200209000-00004

48. Liu X, Wei L, Zeng Q, Lin K, Zhang J. The treatment of topical drugs for postherpetic neuralgia: a network meta-analysis. Pain Physician. 2020;23(6):541-551.

49. Wolff RF, Bala MM, Westwood M, Kessels AG, Kleijnen J. 5\% lidocaine-medicated plaster vs other relevant interventions and placebo for post-herpetic neuralgia (PHN): a systematic review. Acta Neurol Scand. 2011;123(5):295-309. doi:10.1111/j.16000404.2010.01433.x

50. Khaliq W, Alam S, Puri N. Topical lidocaine for the treatment of postherpetic neuralgia. Cochrane Database Syst Rev. 2007;2: CD004846. doi:10.1002/14651858.CD004846.pub2

51. Sabatowski R, Hans G, Tacken I, Kapanadze S, Buchheister B, Baron R. Safety and efficacy outcomes of long-term treatment up to 4 years with $5 \%$ lidocaine medicated plaster in patients with post-herpetic neuralgia. Curr Med Res Opin. 2012;28 (8):1337-1346. doi:10.1185/03007995.2012.707977

52. Hans G, Sabatowski R, Binder A, Boesl I, Rogers P, Baron R. Efficacy and tolerability of a $5 \%$ lidocaine medicated plaster for the topical treatment of post-herpetic neuralgia: results of a long-term study. Curr Med Res Opin. 2009;25(5):1295-1305. doi:10.1185/ 03007990902901368

53. Argoff CE, Galer BS, Jensen MP, Oleka N, Gammaitoni AR. Effectiveness of the lidocaine patch $5 \%$ on pain qualities in three chronic pain states: assessment with the neuropathic pain scale. Curr Med Res Opin. 2004;20(Suppl 2):S21-28. doi:10.1185/ 030079904X12960

54. Snedecor SJ, Sudharshan L, Cappelleri JC, Sadosky A, Mehta S, Botteman M. Systematic review and meta-analysis of pharmacological therapies for painful diabetic peripheral neuropathy. Pain Pract. 2014;14(2):167-184. doi:10.1111/papr.12054

55. Wolff RF, Bala MM, Westwood M, Kessels AG, Kleijnen J. 5\% Lidocaine medicated plaster in painful diabetic peripheral neuropathy (DPN): a systematic review. Swiss Med Wkly. 2010;140(2122):297-306.

56. Barbano RL, Herrmann DN, Hart-Gouleau S, Pennella-Vaughan J, Lodewick PA, Dworkin RH. Effectiveness, tolerability, and impact on quality of life of the $5 \%$ lidocaine patch in diabetic polyneuropathy. Arch Neurol. 2004;61(6):914-918. doi:10.1001/archneur.61.6.914

57. Nalamachu S, Crockett RS, Mathur D. Lidocaine patch 5 for carpal tunnel syndrome: how it compares with injections: a Pilot Study. J Fam Pract. 2006;55(3):209-214.

58. Nalamachu S, Crockett RS, Gammaitoni AR, Gould EM. A comparison of the lidocaine patch $5 \%$ vs naproxen $500 \mathrm{mg}$ twice daily for the relief of pain associated with carpal tunnel syndrome: a 6-Week, Randomized, Parallel-Group Study. MedGenMed. 2006;8(3):33.

59. Moghtaderi AR, Jazayeri SM, Azizi S. EMLA cream for carpal tunnel syndrome: how it compares with steroid injection. Electromyogr Clin Neurophysiol. 2009;49(6-7):287-289. 
60. Hochberg MC, Altman RD, April KT, et al. American college of rheumatology 2012 recommendations for the use of nonpharmacologic and pharmacologic therapies in osteoarthritis of the hand, hip, and knee. Arthritis Care Res (Hoboken). 2012;64(4):465-474. doi:10.1002/acr.21596

61. Kamper SJ, Apeldoorn AT, Chiarotto A, et al. Multidisciplinary biopsychosocial rehabilitation for chronic low back pain. Cochrane Database Syst Rev. 2014;9:CD000963. doi:10.1002/14651858. CD000963.pub3

62. Beaudart C, Biver E, Bruyère $\mathrm{O}$, et al. Quality of life assessment in musculo-skeletal health. Aging Clin Exp Res. 2018;30(5):413-418. doi:10.1007/s40520-017-0794-8

63. Vitaloni M, Botto-van Bemden A, Sciortino Contreras RM, et al. Global management of patients with knee osteoarthritis begins with quality of life assessment: a systematic review. BMC Musculoskelet Disord. 2019;20(1):493. doi:10.1186/s12891-019-2895-3

64. Becker A, Held H, Redaelli M, et al. Low back pain in primary care: costs of care and prediction of future health care utilization. Spine. 2010;35(18):1714-1720. doi:10.1097/brs.0b013e3181cd656f

65. Hestbaek L, Leboeuf-Yde C, Manniche C. Low back pain: what is the long-term course? A review of studies of general patient populations. Eur Spine J. 2003;12(2):149-165. doi:10.1007/s00586-002-0508-5

66. Hashmi JA, Baliki MN, Huang L, et al. Lidocaine patch (5\%) is no more potent than placebo in treating chronic back pain when tested in a randomised double blind placebo controlled brain imaging study. Mol Pain. 2012;8:29. doi:10.1186/1744-8069-8-29

67. Castro E, Dent D. A comparison of transdermal over-the-counter lidocaine $3.6 \%$ menthol $1.25 \%$, Rx lidocaine $5 \%$ and placebo for back pain and arthritis. Pain Manag. 2017;7(6):489-498. doi:10.2217/pmt-2017-0029

68. Baliki MN, Geha PY, Jabakhanji R, Harden N, Schnitzer TJ, Apkarian AV. A preliminary fMRI study of analgesic treatment in chronic back pain and knee osteoarthritis. Mol Pain. 2008;4:47. doi:10.1186/1744-8069-4-47

69. Gimbel J, Linn R, Hale M, Nicholson B. Lidocaine patch treatment in patients with low back pain: results of an open-label, nonrandomized pilot study. Am J Ther. 2005;12(4):311-319. doi:10.1097/01. mjt.0000164828.57392.ba

70. Kivitz A, Fairfax M, Sheldon EA, et al. Comparison of the effectiveness and tolerability of lidocaine patch $5 \%$ versus celecoxib for osteoarthritis-related knee pain: post hoc analysis of a 12 week, prospective, randomized, active-controlled, open-label, parallel-group trial in adults. Clin Ther. 2008;30(12):2366-2377. doi:10.1016/j.clinthera.2008.12.015

71. Burch F, Codding C, Patel N, Sheldon E. Lidocaine patch 5\% improves pain, stiffness, and physical function in osteoarthritis pain patients. A prospective, multicenter, open-label effectiveness trial. Osteoarthritis Cartilage. 2004;12(3):253-255. doi:10.1016/j. joca.2003.10.007

72. Galer BS, Gammaitoni AR, Oleka N, Jensen MP, Argoff CE. Use of the lidocaine patch $5 \%$ in reducing intensity of various pain qualities reported by patients with low-back pain. Curr Med Res Opin. 2004;20(Suppl 2):S5-12. doi:10.1185/030079904X12933

73. Gammaitoni AR, Galer BS, Onawola R, Jensen MP, Argoff CE. Lidocaine patch $5 \%$ and its positive impact on pain qualities in osteoarthritis: results of a pilot 2-week, open-label study using the Neuropathic Pain Scale. Curr Med Res Opin. 2004;20(Suppl 2):S1319. doi:10.1185/030079904X12951

74. Scilex presents ZTlido $^{\mathrm{TM}}$ data on superior adhesion over lidocaine patch formulation. SCILEX Pharmaceutical; September 7, 2018. Available from: https:/www.scilexpharma.com/press-release/scilexpresents-ztlido-data-on-superior-adhesion-over-lidocaine-patchformulation/. Accessed April 15, 2021.
75. Gudin J, Fudin J, Wang E, Haylon T, Patel K, Goss TF. Treatment patterns and medication use in patients with postherpetic neuralgia. J Manag Care Spec Pharm. 2019;25(12):1387-1396. doi:10.18553/ jmcp.2019.19093

76. Moore RA, Chi -C-C, Wiffen PJ, Derry S, Rice ASC. Oral nonsteroidal anti-inflammatory drugs for neuropathic pain. Cochrane Database Syst Rev. 2015;(10):CD010902. doi:10.1002/14651858. CD010902.pub2

77. Snyder MJ, Gibbs LM, Lindsay TJ. Treating painful diabetic peripheral neuropathy: an update. Am Fam Physician. 2016;94(3):227-234.

78. Yang X-D, Fang P-F, Xiang D-X, Yang -Y-Y. Topical treatments for diabetic neuropathic pain. Exp Ther Med. 2019;17(3):1963-1976. doi:10.3892/etm.2019.7173

79. Stanos SP, Galluzzi KE. Topical therapies in the management of chronic pain. Postgrad Med. 2013;125(4 Suppl 1):25-33. doi:10.1080/00325481.2013.1110567111

80. Barkin RL. The pharmacology of topical analgesics. Postgrad Med. 2013;125(4 Suppl 1):7-18. doi:10.1080/00325481.2013.1110566911

81. Pickering G. Antiepileptics for post-herpetic neuralgia in the elderly: current and future prospects. Drugs Aging. 2014;31(9):653-660. doi:10.1007/s40266-014-0202-4

82. Pickering G, Martin E, Tiberghien F, Delorme C, Mick G. Localized neuropathic pain: an expert consensus on local treatments. Drug Des Devel Ther. 2017;11:2709-2718. doi:10.2147/DDDT.S142630

83. Sawynok J. Topical analgesics for neuropathic pain: preclinical exploration, clinical validation, future development. Eur J Pain. 2014;18(4):465-481. doi:10.1002/j.1532-2149.2013.00400.x

84. Topical-medications-in-the-treatment-of-pain.pdf. Available from: http://www.nationalsalesforce.org/wp-content/uploads/2014/08/ Topical-Medications-in-the-Treatment-of-Pain.pdf. Accessed April $15,2021$.

85. Wolfe GI, Barohn RJ. Painful peripheral neuropathy. Curr Treat Options Neurol. 2002;4(3):177-188. doi:10.1007/s11940-002-0034-0

86. Frost SG. Treatment of complex regional pain syndrome type 1 in a pediatric patient using the lidocaine patch 5\%: a case report. Curr Ther Res Clin Exp. 2003;64(8):626-629. doi:10.1016/j. curtheres.2003.09.010

87. Nayak S, Cunliffe M. Lidocaine 5\% patch for localized chronic neuropathic pain in adolescents: report of five cases. Paediatr Anaesth. 2008;18(6):554-558. doi:10.1111/j.1460-9592.2008.02491. $\mathrm{X}$

88. Rasolofo J, Poncelet M, Rousseau V, Marec-Berard P. [Analgesic efficacy of topical lidocaine for vaso-occlusive crisis in children with sickle cell disease]. Arch Pediatr. 2013;20(7):762-767. French. doi:10.1016/j.arcped.2013.04.013

89. Friedrichsdorf SJ, Nugent AP. Management of neuropathic pain in children with cancer. Curr Opin Support Palliat Care. 2013;7 (2):131-138. doi:10.1097/SPC.0b013e3283615ebe

90. Goddard JM, Reaney RL. Lidocaine 5\%-medicated plaster (Versatis) for localised neuropathic pain: results of a multicentre evaluation of use in children and adolescents. Br J Pain. 2018;12(3):189-193. doi:10.1177/2049463718756431

91. Fitzgerald M. The development of nociceptive circuits. Nat Rev Neurosci. 2005;6(7):507-520. doi:10.1038/nrn1701

92. Jorge LL, Feres CC, Teles VE. Topical preparations for pain relief: efficacy and patient adherence. J Pain Res. 2010;4:11-24. doi:10.2147/JPR.S9492

93. Lidocaine (Topical Application Route). Available from: https://www. mayoclinic.org/drugs-supplements/lido865caine-topical-applicationroute/proper-use/drg-2007277. Accessed September 21, 2021. 


\section{Publish your work in this journal}

Drug Design, Development and Therapy is an international, peerreviewed open-access journal that spans the spectrum of drug design and development through to clinical applications. Clinical outcomes, patient safety, and programs for the development and effective, safe, and sustained use of medicines are a feature of the journal, which has also been accepted for indexing on PubMed Central. The manuscript management system is completely online and includes a very quick and fair peer-review system, which is all easy to use. Visit http://www. dovepress.com/testimonials.php to read real quotes from published authors. 